\title{
Impact of the IL-10 Promoter Gene Polymorphisms in the Severity of Chronic Hepatitis B Infection
}

\author{
Sahand Ghaleh Baghi ${ }^{1,2,} ;$ Seyed Moayed Alavian ${ }^{1,3} ;$ Leila Mehrnoush $^{1} ;$ Shima Salimi $^{1}$ \\ ${ }_{1}$ Baqiyatallah Research Center for Gastroenterology and Liver Diseases (BRCGL), Tehran, IR Iran \\ ${ }^{2}$ Department of Otolaryngology and Head and Neck Surgery, Rasool Akram Hospital, Tehran, IR Iran \\ ${ }^{3}$ Middle East Liver Disease Center(MELD), Tehran, IR Iran \\ ${ }^{*}$ Corresponding Author: Sahand Ghaleh Baghi, Department of Otolaryngology and Head and Neck Surgery, Rasool Akram Hospital, Tehran, IR Iran. Tel: +98-9126079880, \\ E-mail: sahandgh65@gmail.com
}

Received: March 6, 2015; Revised: May 22, 2015; Accepted: June 20, 2015

\begin{abstract}
Background: Interleukin-10 (IL-10) is an important anti-inflammatory cytokine. The polymorphisms of its promoter gene have been considered to be related with the chronicity of hepatitis B infection.

Objectives: The aim of this study was to evaluate the polymorphisms at different positions in the IL-10 promoter gene in patients with chronic hepatitis $B$.

Patients and Methods: Totally, 166 patients with chronic hepatitis B infection were enrolled. Genotypes at different positions (i.e. -819, 592, and-1082) in the IL-10 gene promoter were determined.

Results: The C/A genotype at position -592, C/T genotype at position -819, and GCC/ATA haplotype of the IL-10 gene promoter were significantly more common in the patients with cirrhosis. The genotypes were significantly different between the hepatitis B e antigen (HBeAg)-negative and HBeAg-positive patients at position -592 (C/A and C/C), position -819 (C/C and C/T), and position-1082 (A/A and G/A). Conclusions: Some IL-10 promoter gene polymorphisms predisposed the infected hepatitis B virus cases to cirrhosis in our study population.
\end{abstract}

Keywords: Genotype; Interleukin-10; Polymorphism, Genetic; Promoter Regions, Genetic; Liver Cirrhosis

\section{Background}

Hepatitis B virus (HBV) infection is the most common cause of acute and chronic liver disease across much of Asia and Africa (1). Current figures estimate that there are over 400 million carriers globally and 250000 deaths annually due to HBV-associated sequelae (2). The Middle East in particular is experiencing moderate endemic levels of infection with an estimated carrier rate of $2 \%$ to $7 \%$ (3-5). Iran, the setting of the present study, has an estimated prevalence of $2.14 \% \mathrm{HBV}$ infection $(6,7)$. Of the infected patients, approximately $5 \%$ will present with chronic disease and this counteraction between the chronic and acute forms of HBV is largely dependent on the patient's age and immune status at time of infection.

Cytokines, such as interleukins, play an integral role in the host immune response and may be a critical factor in determining the duration and severity of HBV infection (8, 9). Several studies have, therefore, focused on investigating the genetic polymorphisms of key interleukins and their potential effects on both the natural progression of viral hepatitis and its response to modern day treatments (10-13). Interleukin-10 (IL-10) is an important anti-inflammatory cytokine secreted by different cells such as liver cells, $\mathrm{T}$ regulatory lymphocytes, activated macrophages, and $\mathrm{T}$ helper (Th) 2 cells. It inhibits macrophage-dependent antigen presentation, proliferation of T-lymphocytes, and Th1 cytokine secretion and acts as an inhibitor of Th1 effectors mechanism (14-20).

In recent years, evidence has shown that the IL-10 genetic polymorphisms are associated with the chronicity and progression of $\operatorname{HBV}(21,22)$. Five exons on the IL-10 chromosomes and several polymorphic sites in the promoter region have also been identified (23-25). Predominantly, the most common polymorphisms in the IL-10 gene promoter are single-nucleotide polymorphisms (SNPs) at positions $-1082 \mathrm{G} / \mathrm{A},-819 \mathrm{C} / \mathrm{T}$, and - $592 \mathrm{C} / \mathrm{A}$ (25). The T and $C$ alleles at position -819 of the IL-10 promoter gene are considered totally in linkage with the IL-10 - 592 A and $C$ alleles. The allele at position -592 is associated with the -1082 A allele, resulting in three different haplotypes, namely GCC, ACC, and ATA (26).

The functional characteristics of these three SNPs of the IL-10 gene and their association with the production of different cytokines have been demonstrated by several studies $(12,13,16,23,24,27)$. The $-1082 \mathrm{G} / \mathrm{G}$ genotype is associated with a higher IL-10 production, while -1082 G/A and $\mathrm{A} / \mathrm{A}$ are associated with a lower production (28).

Copyright ( 2015, Kowsar Corp. This is an open-access article distributed under the terms of the Creative Commons Attribution-NonCommercial 4.0 International License (http://creativecommons.org/licenses/by-nc/4.0/) which permits copy and redistribute the material just in noncommercial usages, provided the original work is properly cited. 


\section{Objectives}

This study sought to find the impact of different IL-10 promoter gene polymorphisms on patients with chronic $\mathrm{HBV}$ in different stages.

\section{Patients and Methods}

\subsection{Study Subjects}

This study was approved by the Medical Ethics Committee of Baqiyatallah research center for gastroenterology and liver diseases (BRCGL), and signed informed consent was gathered from all the patients before study initiation.

This research panel performed a cross-sectional study of the enrolled patients from the Middle East Liver Disease Center, a specialty referral facility based in Tehran, Iran. Subjects were enrolled from January 2012 through September 2013 and selected based on a minimum criterion of seropositive Hepatitis B surface antigen (HBsAg) status for more than 6 months. The subjects were further sorted into three categories, as is presented in Box 1.

However, the differentiation between Hepatitis B e antigen (HBeAg)-negative chronic active HBV and inactive carrier state is often challenging. A recent study on Iranian patients showed that most HBeAg-negative HBV subjects with serum HBV DNA levels between $2000 \mathrm{IU} /$ $\mathrm{mL}$ and $20000 \mathrm{IU} / \mathrm{mL}$, persistent normal alanine transaminase (ALT) serum concentration, and mild or no liver damage on biopsy could be considered HBV inactive carriers (29).

Patients from Box 1 were then further screened for hepatitis $C$ virus, hepatitis D virus, and human immunodeficiency virus, all of which were confounding factors and criteria for exclusion from the study. In total, 166 subjects were included in our final results.

\subsection{Hepatitis B Virus DNA Extraction}

Peripheral venous blood samples were collected in EDTA tubes and stored at $-20^{\circ} \mathrm{C}$. Genomic DNA was extracted using the QIAamp DNA Mini Kit (Qiagen, Hilden, Germany).

\subsection{Hepatitis B Virus Viral Load Measurement}

HBV viral load measurement was assessed by real-time polymerase chain reaction (PCR) using the Artus LightCycler HBV DNA Kit (Qiagen; Hilden, Germany) and LightCycler 2.0 instrument real-time PCR (Roche, Germany).

\subsection{Interleukin-10 Genotyping}

The polymorphisms in the IL-10 gene promoter at positions $-592,-819$, and -1082 were evaluated via the Polymerase Chain Reaction-Restriction Fragment Length Polymorphism (PCR-RFLP) technique using primers from Shanghai Sangon Biological Engineering Technology and Services Co., Ltd. The primers were as follows:

IL10 - 592: F: 5'GGTGAGCACTACCTGACTAGC3'; R: 5'CCTAGGTCACAGTGACGTGG3'

IL10 - 819: F: 5'TCATTCTATGTGCTGGAGATGG3'; R: 5'TGGGGGAAGTGGGTAAGAGT-3'

IL10 - 1082: F: 5'CCAAGACAACACTACTAAGGCTCCTTT3'; R: 5'GCTTCTTATATGCTAGTCAGGTA3'

PCR conditions were $94^{\circ} \mathrm{C} 5$ minutes; 35 cycles of $30 \mathrm{sec}$ at $94^{\circ} \mathrm{C}, 45 \mathrm{sec}$ at $56^{\circ} \mathrm{C}$, and 1 minute at $72^{\circ} \mathrm{C}$; and $72^{\circ} \mathrm{C} 10$ minutes. Then, the electrophoresis of the PCR products was done, and they were visualized on 3\% agarose gel stained with $0.1 \%$ ethidium bromide.

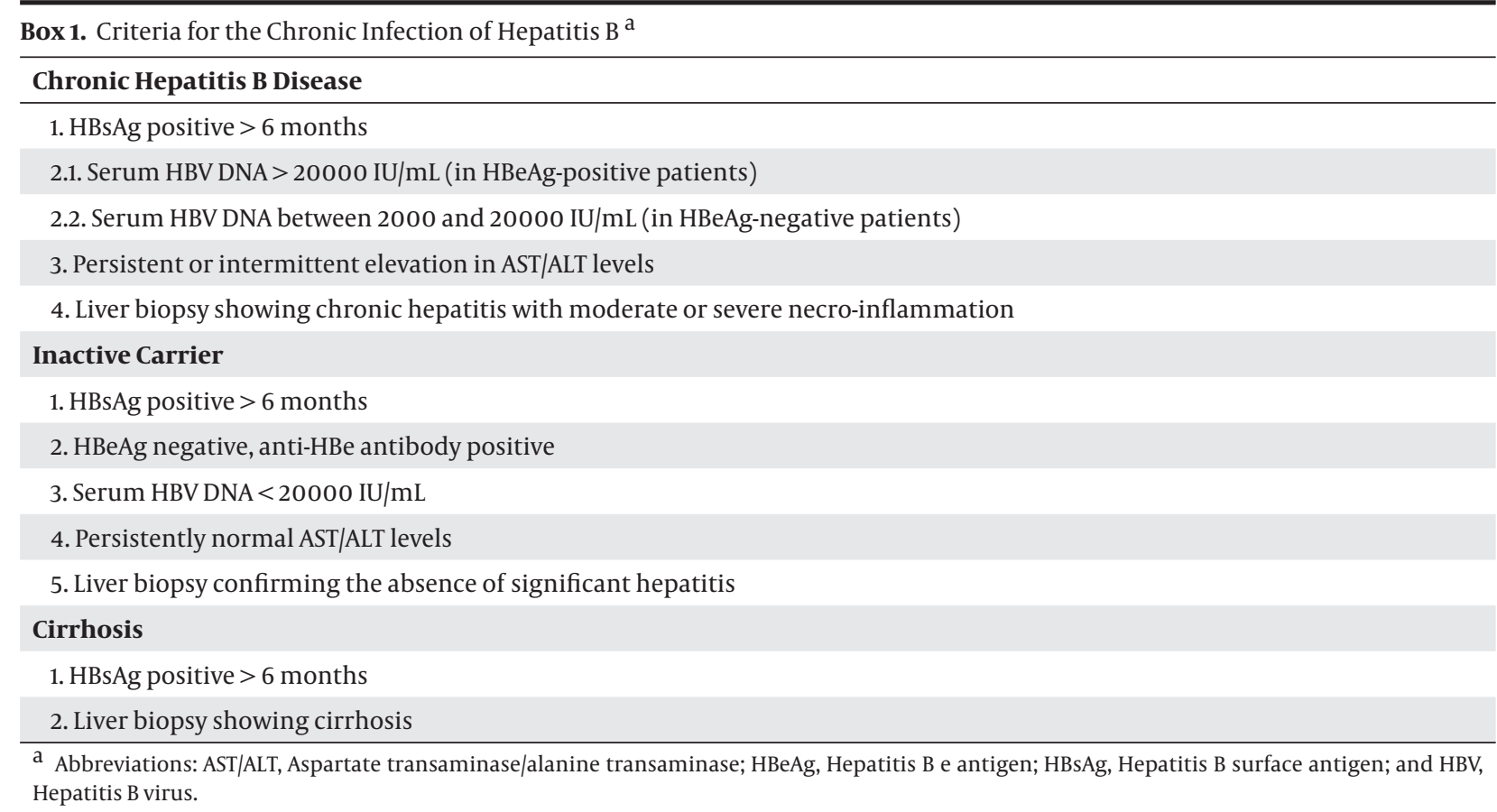


Ghaleh Baghi S et al.

\subsection{Serological Markers}

HBsAg and antibodies to HBsAg (anti-HBs antigen) were measured by enzyme-linked immunosorbent assay (ELISA) using a commercial kit (Hepanostika, BioMérieux, Boxtel, Netherlands). Anti-HBe antibody and HBeAg were measured using Radim Kits (Radim, Barcelona, Spain). All the samples were checked for anti-HDV antibodies with the ELISA kit (Dia. Pro Diagnostic Bioprobes s.r.l., Italy).

\subsection{Statistical Analysis}

Statistical package for the social sciences (SPSS) (SPSS Inc.) version 18 was used for data analysis. The data are presented in frequency. The Pearson $\chi^{2}$ test with the Fisher exact test was used for the assessment of the categorical variables. AP value $<0.05$ was considered statistically significant.

\section{Results}

\subsection{Demographic Information}

Totally, 166 patients were enrolled in this study. Most of them were male and married. About a quarter of the patients had a positive family history of HBV infection. Also, chronic HBV infection was the most frequent type of HBV infection. More details about the demographic analysis are depicted in Table 1.

4.2. Interleukin-10 Promoter Polymorphisms in Chronic Hepatitis B Virus Infection in Different Stages

The IL-10 gene genotypes at positions $-592,-819$, and
-1082 were checked for chronic HBV infection in different stages (i.e. cirrhosis, inactive carrier, and chronic HBV). The genotypes at all the loci did not differ significantly between the groups of chronic HBV infection; however, there was a trend in C/A at locus -592 and C/T at locus -819 to chronic HBV infection (Table 2).

\begin{tabular}{|c|c|}
\hline Parameters & Values \\
\hline Age, $y$ & $38.5 \pm 13.7$ \\
\hline Male & $111(66.8)$ \\
\hline Female & $55(33.2)$ \\
\hline Married & $135(81.3)$ \\
\hline Single & $31(18.7)$ \\
\hline Positive FHx & $42(25.3)$ \\
\hline Negative FHx & $124(74.7)$ \\
\hline HBeAg positive & $46(27.7)$ \\
\hline HBeAb positive & $120(72.3)$ \\
\hline \multicolumn{2}{|l|}{ HBV DNA, IU/mL } \\
\hline Total & $1,597,345(2600-4,815,266)$ \\
\hline HBeAg positive & $3,015,266(238,103-4,815,266)$ \\
\hline HBeAb positive & $640,926(2600-1,573,480)$ \\
\hline HAI-Knodell score & $7.27(0-15)$ \\
\hline
\end{tabular}

Table 2. Gene Promoter Polymorphisms in all the Cases ${ }^{\text {a }}$

\begin{tabular}{|c|c|c|c|c|}
\hline & Cirrhosis $(\mathbf{N}=\mathbf{9})$ & Inactive Carrier $(\mathrm{N}=55)$ & Chronic Hepatitis B Virus $(\mathrm{N}=102)$ & P Value \\
\hline \multicolumn{5}{|c|}{ Locus-592 } \\
\hline $\mathrm{A} / \mathrm{A}$ & $0(0)$ & $3(1.8)$ & $9(5.4)$ & 0.510 \\
\hline $\mathrm{C} / \mathrm{A}$ & $8(4.8)$ & $31(18.7)$ & $49(29.56)$ & 0.052 \\
\hline $\mathrm{C} / \mathrm{C}$ & $1(0.6)$ & $21(12.6)$ & $44(26.5)$ & 0.163 \\
\hline \multicolumn{5}{|c|}{ Locus-819 } \\
\hline $\mathrm{C} / \mathrm{C}$ & $1(0.6)$ & $21(12.6)$ & $44(26.5)$ & 0.163 \\
\hline $\mathrm{C} / \mathrm{T}$ & $8(4.8)$ & $31(18.7)$ & $49(29.6)$ & 0.052 \\
\hline $\mathrm{T} / \mathrm{T}$ & $0(0)$ & $3(1.8)$ & $9(5.4)$ & 0.510 \\
\hline \multicolumn{5}{|c|}{ Locus-1082 } \\
\hline $\mathrm{A} / \mathrm{A}$ & $2(1.2)$ & $23(13.9)$ & $53(31.9)$ & 0.148 \\
\hline G/A & $6(3.6)$ & $23(13.9)$ & $35(21.1)$ & 0.134 \\
\hline G/G & $1(0.6)$ & $9(5.4)$ & $14(8.4)$ & 0.866 \\
\hline
\end{tabular}

a Data are presented as No. (\%). 
4.3. Interleukin-10 Gene Promoter Polymorphisms Comparison between Patients with Cirrhosis and Patients without Cirrhosis

The IL-10 gene genotype and haplotype were compared between the patients with cirrhosis and those without cirrhosis. There was a statically significant difference between the two groups in C/A at locus -592 ( $\mathrm{P}=$ $0.026)$ and $\mathrm{C} / \mathrm{T}$ at locus $-819(\mathrm{P}=0.026)$. The other genotypes did not show any significant differences between the two groups. Also, analysis was not possible between A/A at locus -592 and T/T at locus - 819 because of " 0 " data for cirrhosis (Table 3). The two groups were compared in terms of different haplotypes, which revealed a significant difference only in the GCC/ATA haplotype (P = 0.001) (Table 3).

\subsection{Interleukin-10 Gene Promoter Polymorphisms Comparison between the HBeAg Positives and the HBeAg Negatives}

There was no significant difference between the HBeAgpositive patients. The other genotypes differed significantly between the two groups in our analysis (Table 4).

\begin{tabular}{|c|c|c|c|c|}
\hline & $\operatorname{Cirrhosis}(\mathbf{N}=9)$ & Without Cirrhosis $(\mathrm{N}=157)$ & OR & PValue \\
\hline \multicolumn{5}{|l|}{ Locus -592 } \\
\hline $\mathrm{A} / \mathrm{A}$ & $0(0)$ & $12(7.2)$ & - & 0.238 \\
\hline $\mathrm{C} / \mathrm{A}$ & $8(4.8)$ & $80(48.2)$ & 7.700 & 0.026 \\
\hline $\mathrm{C} / \mathrm{C}$ & $1(0.6)$ & $65(39.2)$ & 0.177 & 0.070 \\
\hline \multicolumn{5}{|l|}{ Locus -819 } \\
\hline $\mathrm{C} / \mathrm{C}$ & $1(0.6)$ & $65(39.2)$ & 0.177 & 0.070 \\
\hline $\mathrm{C} / \mathrm{T}$ & $8(4.8)$ & $80(48.2)$ & 7.700 & 0.026 \\
\hline $\mathrm{T} / \mathrm{T}$ & $0(0)$ & $12(7.2)$ & - & 0.238 \\
\hline \multicolumn{5}{|l|}{ Locus -1082 } \\
\hline $\mathrm{A} / \mathrm{A}$ & $2(1.2)$ & $76(45.8)$ & 0.305 & 0.125 \\
\hline $\mathrm{G} / \mathrm{A}$ & $6(3.6)$ & $58(34.9)$ & 3.414 & 0.074 \\
\hline $\mathrm{G} / \mathrm{G}$ & $1(0.6)$ & $23(13.9)$ & 0.728 & 0.769 \\
\hline \multicolumn{5}{|c|}{ Haplotypes } \\
\hline ACC/ACC & 0 & $15(9)$ & - & 0.184 \\
\hline GCC/GCC & $1(0.6)$ & $23(13.9)$ & 0.728 & 0.769 \\
\hline ATA/ATA & 0 & $12(7.2)$ & - & 0.238 \\
\hline GCC/ACC & 0 & $27(16.3)$ & - & 0.358 \\
\hline GCC/ATA & $6(3.6)$ & $31(18.7)$ & 8.129 & 0.001 \\
\hline ACC/ATA & $2(1.2)$ & $49(29.5)$ & 0.630 & 0.569 \\
\hline
\end{tabular}

a Data are presented as No.(\%).

Table 4. Correlation between HBeAg Seroconversion and IL-10 Genotype and Haplotype a,b

\begin{tabular}{|c|c|c|c|c|}
\hline & HBeAg Positive $(\mathrm{N}=46)$ & HBeAg Negative $(\mathrm{N}=120)$ & OR & P Value \\
\hline \multicolumn{5}{|c|}{ Locus -592} \\
\hline $\mathrm{A} / \mathrm{A}$ & $4(2.4)$ & $8(4.8)$ & 1.333 & 0.651 \\
\hline $\mathrm{C} / \mathrm{A}$ & $14(8.4)$ & $74(44.6)$ & 0.272 & 0.0003 \\
\hline $\mathrm{C} / \mathrm{C}$ & $28(16.9)$ & $38(22.9)$ & 3.357 & 0.0005 \\
\hline \multicolumn{5}{|c|}{ Locus $\mathbf{- 8 1 9}$} \\
\hline $\mathrm{C} / \mathrm{C}$ & $28(16.9)$ & $38(4.8)$ & 3.357 & 0.0005 \\
\hline $\mathrm{C} / \mathrm{T}$ & $14(8.4)$ & $74(44.6)$ & 0.272 & 0.0003 \\
\hline $\mathrm{T} / \mathrm{T}$ & $4(16.9)$ & $8(22.9)$ & 1.333 & 0.651 \\
\hline \multicolumn{5}{|c|}{ Locus -1082 } \\
\hline $\mathrm{A} / \mathrm{A}$ & $12(7.2)$ & $66(39.8)$ & 0.289 & 0.0008 \\
\hline $\mathrm{G} / \mathrm{A}$ & $30(18.1)$ & $34(20.5)$ & 4.743 & 0.000 \\
\hline $\mathrm{G} / \mathrm{G}$ & $4(2.4)$ & $20(12)$ & 0.476 & 0.191 \\
\hline
\end{tabular}

${ }^{\mathrm{a}}$ Data are presented as No.(\%).

b Abbreviation: HBeAg, Hepatitis B e Antigen; IL-10, Interleukin-10. 


\section{Discussion}

The results of the current study showed that the C/A genotype at position -592, C/T genotype at position -819, and A/A genotype at position -1082 of the IL-10 gene promoter were more common than the other genotypes.

These results differ from the findings of comparable prior studies. In a previous study, Cheong et al. (30) found that the A/A genotype at position -592, T/T at position -819, and genotype A/A at position -1082 were higher in the cases with chronic hepatitis B. In their study, the genotypes were significantly different at position -592 between the cases and controls.

In another study conducted by Sofian et al. (31), the C/C genotypes at position -519 and - 819 were higher in the persistent HBV-infected group, while the A/A genotypes were prevalent in the -1082 position. The authors also found that the IL-10 promoter genotypes were not significantly different between the controls, recovered cases, carriers, and chronic hepatitis B patients at the three different positions. Wang et al. (32) evaluated the IL-10 promoter gene polymorphisms in 52 patients with chronic HBV infection and 48 healthy subjects and reported higher A/A, T/T, and A/A genotypes at positions -592, -819, and -1082 in the patients than in the controls, although the difference was not statistically significant.

The results of the present study also showed that the genotypes of C/A at position -592 and C/T at position -819 were significantly different between the patients with cirrhosis and those without cirrhosis $(\mathrm{P}<0.05)$, while the genotypes were not significantly different between the other positions. Also, in the patients with GCC/ATA, there was a significant difference between these two groups ( $P$ $<0.05$ ). Our analysis illustrated that the genotypes of $\mathrm{C} / \mathrm{A}$ and $\mathrm{C} / \mathrm{C}$ at position -592, C/C and C/T at position -819, and $\mathrm{A} / \mathrm{A}$ and G/A at position -1082 were significantly different between the HBeAg-positive and HBeAg-negative patients $(\mathrm{P}<0.05)$. This finding is to some extent consistent with the findings reported by Cheong et al. (30).

The clinical outcome in patients with chronic infectious disease depends on the host immune system and the virulence of the organism. The host genetic factors involving genetic polymorphisms are important in chronic diseases to determine the susceptibility to infection or the disease severity $(22,33,34)$.

In chronic viral hepatitis, genetics is important for predicting viral persistence and disease progression (32). IFN-gamma and TNF-a inhibit HBV replication, while IL-10 negates their effects $(22,35,36)$. IL-10 has immune-regulatory and anti-inflammatory effects, which are produced by Th2 cells, T-regulatory lymphocytes, and activated macrophages (37). The polymorphisms of IL-10 could affect its transcription, translation, and secretion (38). In previous studies, the polymorphisms of the IL-10 gene promoter and the chronicity of HBV infection and disease progression have been evaluated. Different studies have yielded different results. Cheong et al. (30) reported that the genotypes of IL-10, leading to a higher production of IL-10, would lead to better recovery from HBV infection, while Shin et al. (39) found that a higher production of IL-10 would cause the progression of HBV infection. In another study, Turner et al. (28) demonstrated that the A/A genotype at position -519 in the IL-10 promoter genes related to a lower level of IL-10 and a better HBV infection outcome. Wu et al. (40) reported that the G/G genotype polymorphism at position -1082 was correlated with a lower viral load of HBV, whereas Gao et al. (14) found no significant difference in terms of the AA/AG genotypes at position -1082 between the HBV cases and controls in their investigation.

Our results also showed that the genotype of C/A at position -592 and C/T at position -819 and haplotype GCC/ ATA were significantly more prevalent in cirrhosis. Also, C/A and C/C at position -592, C/C and C/T at position -819, and $\mathrm{A} / \mathrm{A}$ and $\mathrm{G} / \mathrm{A}$ at position -1082 were significantly more common in the HBeAg-positive patients.

It should be noted that the low number of the cirrhotic patients in this study impaired our clinical judgment. Also, liver failure, as a complication of HBV infection, was not evaluated in this study. Hence, a further study recruiting larger numbers of cirrhotic patients is necessary. What is also needed is an investigation of liver failure in consequence of HBV infection.

The reasons for the variations in the patterns and clinical outcomes of HBV infection are not completely understood; they are, however, thought to be linked to environmental, virological (viral load and virus genotype), immunological (host innate and adaptive immune responses), and host genetic factors. Evidence shows that the host genetic factors play an important role in determining the outcome of HBV infection. There is an important role for cytokines in the initiation and regulation of immune responses against $\mathrm{HBV}$ infection. Consequently, cytokines may affect susceptibility to hepatitis B infection.

We focused our study on the evaluation of three loci on the IL-10 promoter gene. Our results showed a significant difference with respect to the genotypes at multiple loci between the patients with cirrhosis and those without cirrhosis. Furthermore, the genotype was significantly different between the HBeAg-positive and HBeAg-negative patients. The present study had some limitations. First, it is a single-center study with limited samples. Second, we had no control group. Multi-centric studies with larger sample sizes and healthy subjects are, therefore, recommended.

\section{Acknowledgements}

The authors would like to thank the Middle East Liver Disease Center (MELD) for its collaboration in this study.

\section{Authors' Contributions}

1. Study concept and design: Dr. Seyed Moayed Alavian; 2. Acquisition of data: Dr. Sahand Ghaleh Baghi, Dr. Shima Salimi, and Dr. Leila Mehrnoush; 3. Drafting 
of the manuscript: Dr. Sahand Ghaleh Baghi; 4. Critical revision of the manuscript for important intellectual content: Dr. Seyed Moayed Alavian.

\section{References}

1. Lee WM. Hepatitis B virus infection. $N$ Engl $J$ Med. 1997;337(24):1733-45.

2. Zhang PA, Wu JM, Li Y, Yang XS. Association of polymorphisms of interleukin-18 gene promoter region with chronic hepatitis B in Chinese Han population. World J Gastroenterol. 2005;11(11):1594-8.

3. Gurevich I. Hepatitis Part II. Viral hepatitis B, C, and D. Heart Lung. 1993;22(5):450-6.

4. Rosario Pac M, Arnedo A, Montaner MD, Prieto P, Garcia J, Izuel M, et al. [Epidemic outbreak of hepatitis B from the tattoo in gypsy families]. Rev Esp Salud Publica. 1996;70(1):63-9.

5. Andre F. Hepatitis B epidemiology in Asia, the Middle East and Africa. Vaccine. 2000;18:S20-2.

6. Zali MR, Farhadi A, Masjedi M, Zargar A, Nowroozi A. Epidemiology of hepatitis B in the Islamic Republic of Iran. East Mediterr Health J.1996;2(2):290-8.

7. Eftekhari Y, Kazemi Arababadi M, Hakimi H, Rezazadeh Zarandi E. Common HBV genotype in southeastern Iranian patients. Arch Iran Med. 2010;13(2):147-9.

8. Danis VA, Millington M, Hyland VJ, Grennan D. Cytokine production by normal human monocytes: inter-subject variation and relationship to an IL-1 receptor antagonist (IL-1Ra) gene polymorphism. Clin Exp Immunol.1995;99(2):303-10.

9. Motavaf M, Safari S, Alavian SM. Interleukin 18 Gene Promoter Polymorphisms and Susceptibility to Chronic Hepatitis B Infection: A Review Study. Hepat Month. 2014;14(5):e19879.

10. Sharafi H, Pouryasin A, Alavian SM, Behnava B, Keshvari M, Salimi S, et al. Distribution of IL28B Genotypes in Iranian Patients with Chronic Hepatitis C and Healthy Individuals. Hepat Mon. 2012;12(12):e8387.

11. Wu L, Chen L, Zhou L, Xie H, Wei B, Yin S, et al. Association of interleukin 18 gene promoter polymorphisms with HBV recurrence after liver transplantation in Han Chinese population. Hepat Mon. 2011;11(6):469-74.

12. Kusumoto K, Uto H, Hayashi K, Takahama Y, Nakao H, Suruki R, et al. Interleukin-10 or tumor necrosis factor-alpha polymorphisms and the natural course of hepatitis $C$ virus infection in a hyperendemic area of Japan. Cytokine. 2006;34(1-2):24-31.

13. Oleksyk TK, Thio CL, Truelove AL, Goedert JJ, Donfield SM, Kirk GD, et al. Single nucleotide polymorphisms and haplotypes in the IL10 region associated with HCV clearance. Genes Immun. 2005;6(4):347-57.

14. Gao QJ, Liu DW, Zhang SY, Jia M, Wang LM, Wu LH, et al. Polymorphisms of some cytokines and chronic hepatitis B and $C$ virus infection. World J Gastroenterol. 2009;15(44):5610-9.

15. Grove J, Daly AK, Bassendine MF, Gilvarry E, Day CP. Interleukin 10 promoter region polymorphisms and susceptibility to advanced alcoholic liver disease. Gut. 2000;46(4):540-5.

16. Ladero JM, Fernandez-Arquero M, Tudela JI, Agundez JA, Diaz Rubio M, Benitez J, et al. Single nucleotide polymorphisms and microsatellite alleles of tumor necrosis factor alpha and interleukin-10 genes and the risk of advanced chronic alcoholic liver disease. Liver. 2002;22(3):245-51

17. Ramos JA, Silva R, Hoffmann L, Ramos AL, Cabello PH, Urmenyi TP et al. Association of IL-10, IL-4, and IL-28B gene polymorphisms with spontaneous clearance of hepatitis $C$ virus in a population from Rio de Janeiro. BMC Res Notes. 2012;5:508.

18. Persico M, Capasso M, Persico E, Masarone M, Renzo A, Spano D, et al. Interleukin-10 - 1082 GG polymorphism influences the occurrence and the clinical characteristics of hepatitis $C$ virus infection. J Hepatol. 2006;45(6):779-85.

19. Yee LJ, Tang J, Gibson AW, Kimberly R, Van Leeuwen DJ, Kaslow RA. Interleukin 10 polymorphisms as predictors of sustained response in antiviral therapy for chronic hepatitis $\mathrm{C}$ infection. Hepatology. 2001;33(3):708-12.
20. Moore KW, de Waal Malefyt R, Coffman RL, O'Garra A. Interleukin-10 and the interleukin-10 receptor. Annu Rev Immunol. 2001;19:683-765.

21. Ben-Ari Z, Mor E, Papo O, Kfir B, Sulkes J, Tambur AR, et al. Cytokine gene polymorphisms in patients infected with hepatitis $B$ virus. Am J Gastroenterol. 2003;98(1):144-50.

22. Miyazoe S, Hamasaki K, Nakata K, Kajiya Y, Kitajima K, Nakao K, et al. Influence of interleukin-10 gene promoter polymorphisms on disease progression in patients chronically infected with hepatitis B virus. Am J Gastroenterol. 2002;97(8):2086-92.

23. Lio D, Caruso C, Di Stefano R, Colonna Romano G, Ferraro D, Scola $\mathrm{L}$, et al. IL-10 and TNF- $\alpha$ polymorphisms and the recovery from HCV infection. Hum Immunol. 2003;64(7):674-80.

24. Mangia A, Santoro R, Piattelli M, Pazienza V, Grifa G, Iacobellis A, et al. IL-10 haplotypes as possible predictors of spontaneous clearance of HCV infection. Cytokine. 2004;25(3):103-9.

25. Swiatek BJ. Is interleukin-10 gene polymorphism a predictive marker in HCV infection? Cytokine Growth Factor Rev. 2012;23(12):47-59.

26. Eskdale J, Keijsers V, Huizinga T, Gallagher G. Microsatellite alleles and single nucleotide polymorphisms (SNP) combine to form four major haplotype families at the human interleukin-10 (IL-10) locus. Genes Immun.1999;1(2):151-5.

27. Knapp S, Hennig BJ, Frodsham AJ, Zhang L, Hellier S, Wright M et al. Interleukin-10 promoter polymorphisms and the outcome of hepatitis C virus infection. Immunogenetics. 2003;55(6):362-9.

28. Turner DM, Williams DM, Sankaran D, Lazarus M, Sinnott PJ Hutchinson IV. An investigation of polymorphism in the interleukin-10 gene promoter. Eur J Immunogenet. 1997;24(1):1-8.

29. Keshvari M, Alavian SM, Sharafi H. How Can We Make Decision for Patients With Chronic Hepatitis B According to Hepatitis B Virus (HBV) DNA Level? Hepat Mon. 2014;14(1):e15285.

30. Cheong JY, Cho SW, Hwang IL, Yoon SK, Lee JH, Park CS, et al. Association between chronic hepatitis B virus infection and interleukin-10, tumor necrosis factor-alpha gene promoter polymorphisms. J Gastroenterol Hepatol. 2006;21(7):1163-9.

31. Sofian M, Kalantar E, Aghakhani A, Hosseini S, Banifazl M, Eslamifar A, et al. No correlation between interleukin-10 gene promoter polymorphisms and hepatitis B virus infection outcome. Hepat Mon. 2013;13(5):e8803.

32. Wang S, Huang D, Sun S, Ma W, Zhen Q. Interleukin-10 promoter polymorphism predicts initial response of chronic hepatitis B to interferon alfa. Virol J. 2011;8:28.

33. Peng XM, Huang YS, Ma HH, Gu L, Xie QF, Gao ZL. Interleukin-10 promoter polymorphisms are associated with the mode and sequel of HBeAg seroconversion in patients with chronic hepatitis $\mathrm{B}$ virus infection. Liver Int. 2006;26(3):326-33.

34. Xie HY, Wang WL, Yao MY, Yu SF, Feng XN, Jin J, et al. Polymorphisms in cytokine genes and their association with acute rejection and recurrence of hepatitis $B$ in Chinese liver transplant recipients. Arch Med Res. 2008;39(4):420-8.

35. He XX, Chang Y, Jiang HJ, Tang F, Meng FY, Xie QH, et al. Persistent effect of IFNAR-1 genetic polymorphism on the long-term pathogenesis of chronic HBV infection. Viral Immunol. 2010;23(3):251-7.

36. Gong QM, Kong XF, Yang ZT, Xu J, Wang L, Li XH, et al. Association study of IFNAR2 and IL10RB genes with the susceptibility and interferon response in HBV infection. J Viral Hepat. 2009;16(9):674-80.

37. Pestka S, Krause CD, Sarkar D, Walter MR, Shi Y, Fisher PB. Interleukin-10 and related cytokines and receptors. Annu Rev Immunol. 2004;22:929-79.

38. Lu YL, Wu X, Huang HL, Dai LC. Allele polymorphisms of interleukin-10 and hepatitis B, C virus infection. Chin Med J (Engl). 2010;123(10):1338-44

39. Shin HD, Park BL, Kim LH, Jung JH, Kim JY, Yoon JH, et al. Interleukin 10 haplotype associated with increased risk of hepatocellular carcinoma. Hum Mol Genet. 2003;12(8):901-6.

40. Wu JF, Ni YH, Lin YT, Lee TJ, Hsu SH, Chen HL, et al. Human interleukin-10 genotypes are associated with different precore/core gene mutation patterns in children with chronic hepatitis B virus infection. J Pediatr. 2011;158(5):808-13. 